\title{
Therapy of AL amyloidosis - work-up and treatment at our centre
}

\author{
C. Kimmich, U. Hegenbart, H. Goldschmidt, A. D. Ho, S. Schönland
}

Amyloidosis Centre and Department of Medicine V, University of Heidelberg, Heidelberg, Germany

Received 7 November 2011; accepted 5 March 2012

Systemic light-chain amyloidosis (AL amyloidosis) is a rare protein folding disorder in which monoclonal light chains are deposited as insoluble fibrillar aggregates. The most common cause of the disease is a monoclonal plasma cell disorder. Currently, the only clinically relevant treatment option is chemotherapy, targeting the underlying neoplastic cells. Patients are often in a poor general state of health with organ functions being impaired by amyloid deposits. In recent years, several new treatment protocols have been introduced, which give clinicians a variety of options to adapt treatment to the patients' needs. For this reason a thorough assessment must be performed so that each patient receives the best individual treatment option.

Key words: AL amyloidosis, diagnostics, treatment regimens, chemotherapy.

\section{Introduction}

There are three major subtypes of systemic amyloidosis. Firstly, the most common type is AL amyloidosis, which is caused by a deposition of amyloid formed by monoclonal free light chains. Secondly, AA amyloidosis, which is caused by a deposition of serum amyloid A in chronic inflammatory disease. Thirdly, ATTR amyloidosis, which is caused by a deposition of transthyretin due to hereditary gene mutations or rarely also without a mutation in older age. Furthermore several other systemic and local amyloidosis of hereditary (e.g. ApoA1, ApoA2, Fibrinogen, Gelsolin), dialysis-associated (e.g. ß2microglobuline) and iatrogenic (insulin) origin have been described $[1,2]$.

At this point in time, there is no drug or method available which has successfully freed organs from deposited amyloid. Recently, drugs have been developed in ATTR amyloidosis which prevent the precursor protein from misfolding. For each subtype of amyloidosis, the main focus of treatment currently relies on eradication or reduction of the precursor protein to stop or at least slow down the deposition

Correspondence: Stefan Schönland, MD, Amyloidosis Centre and Department of Medicine V, University of Heidelberg, Im Neuenheimer Feld 410, 69120 Heidelberg, Germany.

E-mail: stefan.schoenland@med.uni-heidelberg.de process. In AA amyloidosis this can be achieved by treating the underlying inflammatory disease, in ATTR amyloidosis a liver transplantation will stop the production of mutated transthyretin and in AL amyloidosis, chemotherapy is the method of choice targeting monoclonal light chain producing neoplastic cells.

This article will focus on the therapy of AL amyloidosis, the most common subtype of amyloidosis in Europe [1]. Special attention will be given to treatment regimens, treatment selections as well as risks and limitations.

\section{Assessment prior to treatment initiation}

Before initiating chemotherapy the diagnosis of AL amyloidosis, organ involvement and the underlying haematological disease must be thoroughly assessed.

The diagnosis of amyloidosis is based on the histopathological finding of amyloid deposits in tissue. With a concurrent presence of a monoclonal gammopathy, systemic $\mathrm{AL}$ amyloidosis is likely, but not yet proven. The presence of certain stigmata (e.g. periorbital bleedings (Fig. 1), enlarged tongue (Fig. 2)), which will secure the diagnosis of systemic AL amyloidosis, can only be found in a minority of patients. In the majority of cases a reference pathologist should be consulted for subtype analysis by immunohistochemistry [3]. Laser microdissection and mass spectrometry-based proteomic analysis have to be considered at this point when subtype analysis by immunohistochemistry has been unsuccessful [4]. Furthermore, hereditary amyloidosis should be excluded by genetic testing in the case of inconclusive or nonconclusive immunohistochemistry associated with certain organ involvement patterns (e.g. heart and/or polyneuropathy in TTR) or single organ involvement (e.g. kidney in Fib-alpha).

Systemic AL amyloidosis is proven when AL amyloid is detected in subcutaneous fat, kidneys, liver, nerves or spleen. In all other cases further work-up to rule out localized AL amyloidosis has to be performed. All patients with a positive tissue biopsy from an organ not specific for systemic disease need further investigations. Either a second congored positive biopsy from another site or typical clinical findings of additional organ involvement (see Table 1) must be available to diagnose systemic AL amyloidosis. Congored staining of previously performed biopsies should be requested, if not 


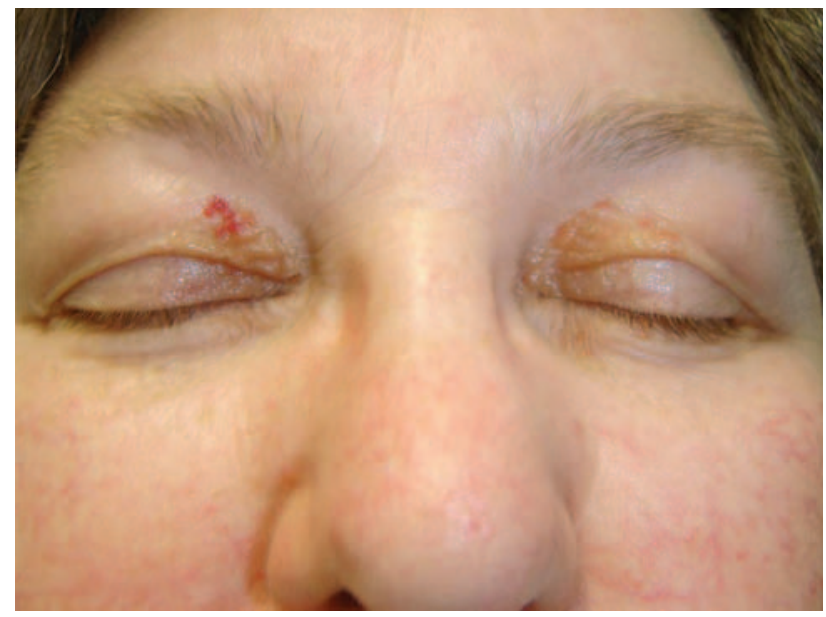

Fig. 1: Periorbital bleeding right eyelid

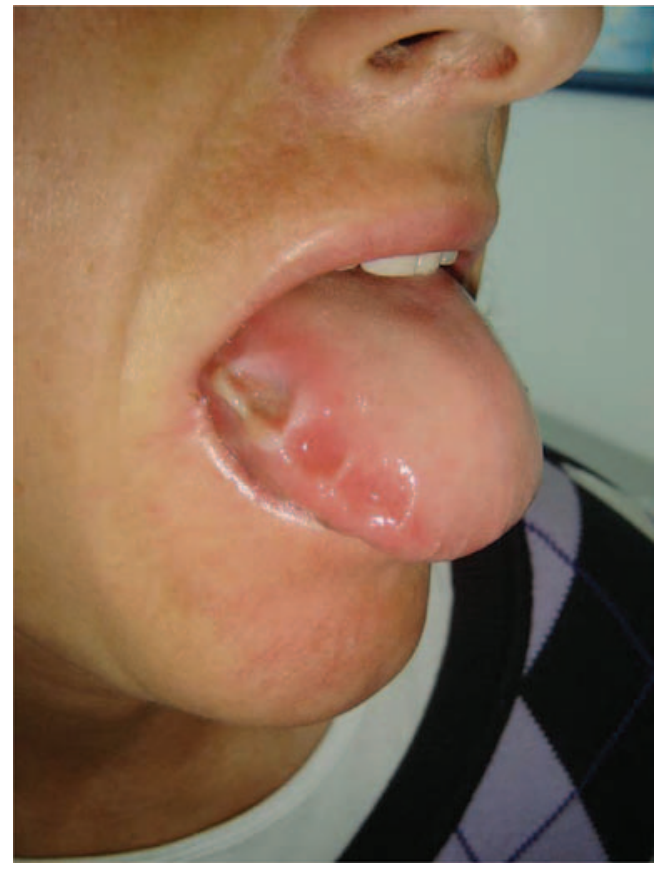

Fig. 2: Macroglossia

available preferably minor invasive procedures such as subcutaneous (abdominal) fat, minor saliva gland, rectum or gingiva biopsies should be performed. Localized AL amyloidosis is very likely when no underlying monoclonal gammopathy can be detected and an isolated organ involvement of skin, lung, larynx or urinary tract is present.

It has to be stated that treating hereditary types of amyloidosis or localized AL amyloidosis with chemotherapy is medical malpractice.

The monoclonal gammopathy is most commonly caused by a plasma cell disorder in the bone marrow (multiple myeloma, monoclonal gammopathy), in less than $10 \%$ the underlying cause is an indolent $\mathrm{B}$ cell lymphoma (Morbus Waldenström, MALT or other secretory B cell lymphoma). In order to diagnose the underlying disease and screen for symptomatic multiple myeloma further work up has to be done. This should include bone marrow diagnostics, imaging studies (preferably a whole-body low dose CT scan to exclude bone lesions in multiple myeloma, if not available a standard $\mathrm{X}$-ray bone status; CT and/or MRI scans to exclude extramedullary plasmocytoma, Castleman's disease or lymphoma) and occasionally further biopsies.

Before treatment initiation the underlying haematological disorder and its activity must be diagnosed and quantified as precisely as possible and a thorough assessment of organ functionality and involvement has to be performed. With these findings each patient can be offered the best individual treatment option and later treatment and organ response can be reliably evaluated.

The work-up before treatment for the haematological disorder should include a serum-free light chain (FLC) assay (elevated kappa or lambda light chain, pathologic FLC ratio or FLC difference), an immunofixation, an immunoglobuline quantification, a protein electrophoresis and if a monoclonal protein is present, a quantification of the monoclonal protein. Additionally, immunofixation with light chain quantification of a 24-hour urine sample should be performed. Using these methods, the underlying monoclonal gammopathy can be traced in more than $90 \%$ of patients with AL amyloidosis [5].

For assessment of organ functionality, involvement and response, according to the 2004 consensus statement, as well as our suggested work-up for amyloidosis patients and MGUS/multiple myeloma patients suspicious for AL amyloidosis please refer to Table 1 .

\section{Drugs}

For AL amyloidosis originating from plasma cell disorders basically the same agents as in multiple myeloma treatment can be used, but with reduced dosages. With B cell disorders, lymphoma treatment regimens like Rituximab in combination with chemotherapy should be applied.

The eldest active agent still in use is Melphalan, either as a single agent in the high dose setting or in low dose in combination with dexamethasone in repetitive treatment cycles. The next drug which was established for treatment was thalidomide, most commonly used in the U.K. in combination with cyclophosphamide and dexamethasone [6]. "Modern drugs" which are regularly used are bortezomib or lenalidomide, each in combination with dexamethasone also given in repetitive cycles. Lately, also combinations of old regimens with modern drugs have successfully been introduced (see Table 2).

\section{First-line treatment}

The best long-term results are currently available for high dose melphalan followed by autologous stem cell transplantation with best median event-free $(2,6$ years) and overall survival (6,3 years) [7] and the best available long-term results for patients achieving a complete remission [8]. Since this is the most intense treatment it comes with the highest rate of severe complications and has the highest treatmentassociated mortality. Thanks to a stricter patient selection, treatment associated mortality could be reduced to below $10 \%$ in specialised centres [7]. Patients with a symptomatic 
Tab. 1: Organ involvement, evaluation and work-up [12]

\begin{tabular}{llllll}
$\begin{array}{l}\text { Organ } \\
\text { involved }\end{array}$ & Typical findings & $\begin{array}{l}\text { Definition of } \\
\text { involvement }\end{array}$ & $\begin{array}{l}\text { Defining organ } \\
\text { response }\end{array}$ & $\begin{array}{l}\text { Defining organ } \\
\text { progression }\end{array}$ & $\begin{array}{l}\text { Suggested work-up, also } \\
\text { recommended for MGUS/ } \\
\text { myeloma patients } \\
\text { suspicious for amyloidosis }\end{array}$ \\
\hline
\end{tabular}

\begin{tabular}{|c|c|c|c|c|c|}
\hline Kidney & $\begin{array}{l}\text { albuminuria }>0,5 \mathrm{~g} / \\
\text { day with nephrotic } \\
\text { syndrome and no } \\
\text { other cause, in } \\
\text { later stages chronic } \\
\text { kidney failure with } \\
\text { progressive GFR } \\
\text { reduction }\end{array}$ & $\begin{array}{l}\text { 1. positive renal } \\
\text { biopsy + organ } \\
\text { dysfunction } \\
\text { 2. positive biopsy } \\
\text { at other site + } \\
\text { typical findings }\end{array}$ & $\begin{array}{l}50 \% \text { decrease (at } \\
\text { least } 0.5 \mathrm{~g} / \text { day) of } \\
24 \mathrm{~h} \text { urine, protein } \\
\text { loss (urine protein } \\
\text { must be }>0.5 \mathrm{~g} / \\
\text { day pretreatment) } \\
\text { creatinine and } \\
\text { creatinine clearance } \\
\text { must not worsen by } \\
25 \% \text { over baseline }\end{array}$ & $\begin{array}{l}50 \% \text { increase (at least } \\
1 \mathrm{~g} / \text { day) of urine protein } \\
\text { loss to greater than } 1 \mathrm{~g} / \\
\text { day or } 25 \% \text { worsening } \\
\text { of serum creatinine or } \\
\text { creatinine clearance }\end{array}$ & $\begin{array}{l}\text { Patient history (nycturia, swollen } \\
\text { legs, itchiness) Clinical examination } \\
\text { (peripheral edema, ascites) Blood } \\
\text { analysis (creatinine, total protein, } \\
\text { albumin, cholesterol and triglycerides) } \\
\text { 24h urine (proteinuria, albuminuria, } \\
\text { creatinine-clearance) }\end{array}$ \\
\hline Heart & $\begin{array}{l}\text { low voltage on ECG } \\
\text { and/or septal wall } \\
\text { thickness }>12 \mathrm{~mm} \\
\text { without hypertension, } \\
\text { reduced LV strain on } \\
\text { echocardiography } \\
\text { accompanied by } \\
\text { elevated NT-proBNP } \\
\text { and troponine }\end{array}$ & $\begin{array}{l}\text { 1. positive } \\
\text { endomyocardial } \\
\text { biopsy + organ } \\
\text { dysfunction } \\
\text { 2. positive biopsy } \\
\text { at other site + } \\
\text { typical findings }\end{array}$ & $\begin{array}{l}\text { Mean interventricular } \\
\text { septal thickness } \\
\text { decrease by } 2 \mathrm{~mm} \text {, } \\
20 \% \text { improvement } \\
\text { in ejection fraction, } \\
\text { improvement by } 2 \\
\text { NYHA classes without } \\
\text { an increase in diuretic } \\
\text { use, no increase in } \\
\text { wall thickness }\end{array}$ & $\begin{array}{l}\text { Interventricular septal } \\
\text { thickness increased by } \\
2 \text { mm compared with } \\
\text { baseline } \\
\text { An increase in NYHA } \\
\text { class by } 1 \text { grade with } \\
\text { a decreasing ejection } \\
\text { fraction of } 10 \%\end{array}$ & $\begin{array}{l}\text { Patient history (symptoms of } \\
\text { progressive heart failure) Clinical } \\
\text { examination (low blood pressure, } \\
\text { peripheral edema, pleura effusion, } \\
\text { ascites), Blood analysis (NT-ProBNP, } \\
\text { troponine), Echocardiography, ECG, } \\
\text { Cardiac MRI, Heart scintigraphy }\end{array}$ \\
\hline Liver & $\begin{array}{l}\text { hepatomegaly } \\
\mathrm{cc}>15 \mathrm{~cm} \text { alkaline } \\
\text { phosphatase } 1,5 \mathrm{x} \\
\text { upper laboratory limit } \\
\text { without other cause }\end{array}$ & $\begin{array}{l}\text { 1. positive liver } \\
\text { biopsy with } \\
\text { interstitial deposits } \\
\text { of amyloid + organ } \\
\text { dysfunction } \\
\text { 2. positive biopsy } \\
\text { at other site + } \\
\text { typical findings }\end{array}$ & $\begin{array}{l}50 \% \text { decrease in } \\
\text { abnormal alkaline } \\
\text { phosphatase value } \\
\text { Decrease in liver size } \\
\text { radiographically at } \\
\text { least } 2 \mathrm{~cm}\end{array}$ & $\begin{array}{l}50 \% \text { increase of alkaline } \\
\text { phosphatase above the } \\
\text { lowest value }\end{array}$ & $\begin{array}{l}\text { Patient history (abdominal pain, } \\
\text { itchiness, drowsiness) Clinical } \\
\text { examination (enlarged hard liver, } \\
\text { jaundice) Abdominal sonar, Blood } \\
\text { analysis (AP, GGT, bilirubin, (GOT,GPT), } \\
\text { coagulation) }\end{array}$ \\
\hline Gl tract & $\begin{array}{l}\text { weight loss, diarrhoea, } \\
\text { constipation, } \\
\text { abdominal pain and } \\
\text { bleeding }\end{array}$ & $\begin{array}{l}\text { 1. positive Gl tract } \\
\text { biopsy + typical } \\
\text { symptoms } \\
\text { 2. positive biopsy } \\
\text { at other site + } \\
\text { typical symptoms }\end{array}$ & * & * & $\begin{array}{l}\text { Patient history for typical findings } \\
\text { Endoscopy with biopsy (only to be } \\
\text { avoided in patients with bleeding } \\
\text { complications) }\end{array}$ \\
\hline $\begin{array}{l}\text { Peripheral } \\
\text { nerve }\end{array}$ & $\begin{array}{l}\text { symmetric ascending } \\
\text { sensorimotor } \\
\text { peripheral neuropathy }\end{array}$ & $\begin{array}{l}\text { 1. positive nerve } \\
\text { biopsy + typical } \\
\text { findings } \\
\text { 2. positive biopsy } \\
\text { at other site }+ \\
\text { typical findings }\end{array}$ & $\begin{array}{l}\text { Improvement in } \\
\text { electromyogram nerve } \\
\text { conduction } \\
\text { velocity (rare) }\end{array}$ & $\begin{array}{l}\text { Progressive neuropathy } \\
\text { by electromyography } \\
\text { or nerve conduction } \\
\text { velocity }\end{array}$ & $\begin{array}{l}\text { Patient history (ascending numbness } \\
\text { and neuropathic pain) Clinical } \\
\text { Examination (pallhypaesthia, } \\
\text { decreased myotatic reflexes) } \\
\text { Neurophysiology (electroneurogram, } \\
\text { electromyogram, small fiber studies) }\end{array}$ \\
\hline $\begin{array}{l}\text { Autonomic } \\
\text { nerve }\end{array}$ & $\begin{array}{l}\text { bowel and bladder } \\
\text { dysfunction, low blood } \\
\text { pressure without other } \\
\text { cause }\end{array}$ & $\begin{array}{l}\text { 1. positive biopsy } \\
\text { at other site }+ \\
\text { typical findings }\end{array}$ & * & * & $\begin{array}{l}\text { Patient history (dizziness, orthostatic } \\
\text { collapse, constipation, vomiting, } \\
\text { overflowing bladder, weight loss), } \\
\text { Clinical examination (low blood } \\
\text { pressure, Schellong test, decreased or } \\
\text { increased bowel movement) }\end{array}$ \\
\hline Soft tissue & $\begin{array}{l}\text { tongue enlarged, } \\
\text { periorbital bleeding, } \\
\text { arthropathy, enlarged } \\
\text { lymph nodes, } \\
\text { blistering/ bleeding } \\
\text { of skin, muscular } \\
\text { pseudohypertrophy }\end{array}$ & $\begin{array}{l}\text { 1. positive biopsy + } \\
\text { typical findings }\end{array}$ & * & * & $\begin{array}{l}\text { Patient history and clinical } \\
\text { examination for typical findings }\end{array}$ \\
\hline
\end{tabular}

cardiac involvement are at highest risk to suffer life-threatening complications, so these patients are primarily excluded. At our centre, we are currently also excluding patients with a deranged kidney function (MDRD below 30), which are at high risk of developing acute-on-chronic kidney failure fol- lowing high-dose chemotherapy. Our patients are monitored in our haematological intensive care unit, where melphalan in total dose of $200 \mathrm{mg} / \mathrm{m}^{2}$ is infused over two days. On the fourth day the autologous stem cell transplantation is performed, from then on patients need on average $3 \frac{1}{2} 2$ weeks for 
Tab. 2: Treatment options in systemic AL amyloidosis

\begin{tabular}{|c|c|c|c|c|c|}
\hline $\begin{array}{l}\text { Treatment } \\
\text { regimen }\end{array}$ & Eligibility & Cycles & Nota bene & Recommended dosages & $\begin{array}{l}\text { Further } \\
\text { information }\end{array}$ \\
\hline $\begin{array}{l}\text { Melphalan/ } \\
\text { Dexamethasone [9] }\end{array}$ & $\begin{array}{l}\text { older patients, low } \\
\text { disease burden }\end{array}$ & $\begin{array}{l}6-9 \text { cycles, } \\
28 \text { days each }\end{array}$ & & $\begin{array}{l}\text { Melphalan } 0,22 \mathrm{mg} / \mathrm{kg} \mathrm{d} 1-4 \\
\text { (or iV } 16 \mathrm{mg} / \mathrm{m}^{2} \text { day } 1 \text { ) + } \\
\text { Dexamethasone } 20-40 \mathrm{mg} \mathrm{d} 1-4\end{array}$ & well tolerated \\
\hline $\begin{array}{l}\text { High-dose melphalan } \\
+ \text { autologous stem cell } \\
\text { transplantation [13] }\end{array}$ & $\begin{array}{l}\text { age }<70, \text { ECOG }<2 \\
\text { NYHA }<3, \text { MDRD }>30\end{array}$ & & $\begin{array}{l}\text { experienced centres } \\
\text { with dedicated ICU }\end{array}$ & $\begin{array}{l}\text { Melphalan } 100 \mathrm{mg} / \mathrm{m}^{2} \mathrm{~d} 1,2+ \\
\text { ABSCT d4 }\end{array}$ & $\begin{array}{l}\text { patients on dialysis } \\
\text { eligible (reduced dose) }\end{array}$ \\
\hline $\begin{array}{l}\text { Bortezomib weekly or } \\
\text { twice a week [14] }\end{array}$ & cardiac involvement & $\begin{array}{l}6-8 \text { cycles, } 35 \\
\text { or } 21 \text { days each }\end{array}$ & $\begin{array}{l}\text { viral prophylaxis } \\
\text { necessary }\end{array}$ & $\begin{array}{l}\text { Bortezomib } 1,3 \mathrm{mg} / \mathrm{m}^{2} \mathrm{~d} 1,8,15,22 \\
\text { or } 1,4,8,11\end{array}$ & $\begin{array}{l}\text { may be increased to } \\
1,6 \mathrm{mg} / \mathrm{m}^{2} \text { in the once } \\
\text { weekly schedule }\end{array}$ \\
\hline $\begin{array}{l}\text { Bortezomib/ } \\
\text { Dexamethasone [10] }\end{array}$ & $\begin{array}{l}\text { for fast light chain } \\
\text { reduction }\end{array}$ & $\begin{array}{l}6-8 \text { cycles, } 21 \\
\text { days each }\end{array}$ & $\begin{array}{l}\text { viral prophylaxis } \\
\text { necessary }\end{array}$ & $\begin{array}{l}\text { starting dose of Bortezomib } \\
1,0 \mathrm{mg} / \mathrm{m}^{2} \mathrm{~d} 1,4,8,11+ \\
\text { Dexamethasone } 8 \mathrm{mg} \\
\mathrm{d} 1,2,8,9,15,16,22,23\end{array}$ & $\begin{array}{l}\text { may be increased to } \\
1,3 \mathrm{mg} / \mathrm{m}^{2}\end{array}$ \\
\hline $\begin{array}{l}\text { Lenalidomide/ } \\
\text { Dexamethasone [15] }\end{array}$ & $\begin{array}{l}\text { mainly for recurrent } \\
\text { disease }\end{array}$ & $\begin{array}{l}6-12 \text { cycles, } 28 \\
\text { days each }\end{array}$ & $\begin{array}{l}\text { thrombosis } \\
\text { prophylaxis } \\
\text { necessary }\end{array}$ & $\begin{array}{l}\text { starting dosage Lenalidomide } \\
15 \mathrm{mg} \text { per day d1-21 + } \\
\text { Dexamethasone } 40 \mathrm{mg} \text { d1-4 }\end{array}$ & $\begin{array}{l}\text { dosage may have to } \\
\text { be adapted to kidney } \\
\text { function }\end{array}$ \\
\hline $\begin{array}{l}\text { Lenalidomide/ } \\
\text { Melphalan/ } \\
\text { Dexamethasone [11] }\end{array}$ & trials & $\begin{array}{l}6 \text { cycles, } 28 \\
\text { days each }\end{array}$ & $\begin{array}{l}\text { thrombosis } \\
\text { prophylaxis } \\
\text { necessary }\end{array}$ & $\begin{array}{l}\text { Lenalidomide } 10-15 \mathrm{mg} \text { per day } \\
\mathrm{d} 1-\mathrm{d} 21+\text { Melphalan } 0,22 \mathrm{mg} / \mathrm{kg} \\
\mathrm{d} 1-4 \text {, Dexamethasone } 20 \mathrm{mg} \mathrm{d} 1-4\end{array}$ & $\begin{array}{l}\text { dosage may have to } \\
\text { be adapted to kidney } \\
\text { function }\end{array}$ \\
\hline
\end{tabular}

physical recovery until they can be discharged. The melphalan itself is normally well tolerated, occasionally, in patients with severe gastrointestinal organ involvement a prolonged interval of nausea might occur. Infections during aplasia pose the biggest threat, for this reason patients should be treated as inpatients to ensure immediate response. Highdose chemotherapy is our treatment of choice in physically fit $($ ECOG <2) patients, with a biological age not older than 70 , without symptomatic cardiac involvement and a good renal function. When a patient is already on dialysis, renal function is no longer a decisive factor. The melphalan dose has to be adapted though. In patients with high disease activity or a symptomatic multiple myeloma an induction therapy, e.g. with bortezomib and/or dexamethasone, might be performed.

In our centre the stem cell collection prior to high-dose melphalan is done after mobilisation chemotherapy with cyclophosphamid, adriamycin (for patients without cardiac involvement) and dexamethasone and G-CSF stimulation from day eight. The basic idea is that we can assess how the patient reacts to a potent chemotherapy, already achieve an effect against the plasma cell disorder and potentially collect more stem cells. In other centres the standard of stem cell collection is solely G-CSF.

Low dose melphalan in combination with dexamethasone is the current standard in therapy for patients with $\mathrm{AL}$ amyloidosis who are not eligible for high dose chemotherapy. The treatment is normally well tolerated. Occasionally patients will develop gastrointestinal side effects. Drops in blood counts might occur after several treatment cycles. The response rate is approximately $60 \%$ [9]. An antibiotic prophylaxis at least during the first treatment cycle is advisable.

Bortezomib is a highly active agent against plasma cell disorders and is part of the standard induction therapy in symptomatic multiple myeloma for more than five years now.
It is a fast working agent with a high response rate (approximately $80 \%$ ) [10]. It is commonly applied in combination with dexamethasone like in multiple myeloma treatment, although the dexamethasone dose should be lowered. Bortezomib as a single agent is also feasible [14]. A viral prophylaxis with acyclovir to prevent zoster reactivation is compulsory. Patients often experience gastrointestinal side effects such as nausea, diarrhoea, constipation or loss of appetite. A progressive painful polyneuropathy with burning sensations might develop under treatment and be persistent. This side effect should be monitored and for patients with an existing polyneuropathy Bortezomib should not be used first-line.

Bortezomib is our agent of choice in individuals who are not eligible for high dose chemotherapy due to symptomatic cardiac involvement or progressively impaired renal function with a high disease activity to achieve a rapid haematological response [10].

\section{Second-line treatment and treatment of recurrent disease}

All regimens for first-line treatment listed above are also suitable for second-line treatment; even giving the same treatment again is after a long remission period feasible. Without a sufficient treatment response, amyloidosis will progress and organ functions will further deteriorate. For this reason an insufficient treatment should not be continued. Before initiating a second-line treatment or a treatment switch a thorough work-up for disease activity and organ involvement must be performed again.

Lenalidomide is currently mainly given in second-line treatment, although in combination with melphalan and dexamethasone it is now also used in first-line therapy within clinical trials [11]. As it is in myeloma treatment commonly applied in combination with dexamethasone. The increased 
risk for thrombosis must be considered and prophylactic anticoagulation should be started ahead of treatment. A fatigue syndrome is another common side effect during treatment.

\section{Limitations}

Patients often have a long medical history from first symptoms until being diagnosed with AL amyloidosis. Early diagnosis of the disease is still a problem. Multi-organ involvement and poor organ functions are commonly present. For this reason, the majority of patients are not eligible for all treatment options. And even after a successful treatment with the underlying disease being in a good remission, patients are often still not healthy due to their impaired organ functions. While on treatment, patients rarely experience an improvement of symptoms, which might cause a compliance problem.

There are none of the above-mentioned drugs approved for therapy of AL amyloidosis in Germany. Currently, clinical studies are planned or ongoing which investigate new treatment approaches against amyloid formation.

\section{Conclusion}

The most important factors for a successful therapy of $\mathrm{AL}$ amyloidosis are a precise pre-treatment assessment, a thorough clinical monitoring of treatment success and a life-long continuation of follow-ups to detect recurrence or progression of the underlying monoclonal gammopathy. New developments in multiple myeloma treatment are being made at a fast level, so further treatment options should soon be available. Creating a higher level of awareness must still be on the agenda to earlier establish the diagnosis of this life-threatening disease.

\section{Conflict of interest}

The authors declare that there is no conflict of interest.

\section{References}

[1] Merlini G, Seldin DC, Gertz MA. Amyloidosis: pathogenesis and new therapeutic options. J Clin Oncol, 29(14): 1924-33, 2011.

[2] Sipe JD, Benson MD, Buxbaum JN, Ikeda S, Merlini G, Saraiva MJ, Westermark P. Amyloid fibril protein nomenclature: 2010 recom- mendations from the nomenclature committee of the International Society of Amyloidosis. Amyloid, 17(3-4): 101-4, 2010.

[3] Schönland SO, Hegenbart U, Bochtler T, Mangatter A, Hansberg M, Ho AD, Lohse P, Röcken C. Immunohistochemistry in the classification of systemic forms of amyloidosis: a systematic investigation of 117 patients. Blood, 119(2): 488-93, 2012.

[4] Vrana JA, Gamez JD, Madden BJ, Theis JD, Bergen HR 3rd, Dogan A. Classification of amyloidosis by laser microdissection and mass spectrometry-based proteomic analysis in clinical biopsy specimens. Blood, 114(24): 4957-9, 2009.

[5] Bochtler T, Hegenbart U, Heiss C, Benner A, Cremer F, Volkmann M, Ludwig J, Perz JB, Ho AD, Goldschmidt H, Schonland SO. Evaluation of the serum-free light chain test in untreated patients with AL amyloidosis. Haematologica, 93(3): 459-62, 2008.

[6] Wechalekar AD, Goodman HJ, Lachmann HJ, Offer M, Hawkins PN, Gillmore JD. Safety and efficacy of risk-adapted cyclophosphamide, thalidomide, and dexamethasone in systemic AL amyloidosis. Blood, 109(2): 457-64, 2007.

[7] Cibeira MT, Sanchorawala V, Seldin DC, et al. Outcome of AL amyloidosis after high-dose melphalan and autologous stem cell transplantation: long-term results in a series of 421 patients. Blood, 118(16): 4346-52, 2011.

[8] Gertz MA, Lacy MQ, Dispenzieri A, et al. Autologous stem cell transplant for immunoglobulin light chain amyloidosis: a status report. Leuk Lymphoma, 51(12): 2181-7, 2010.

[9] Palladini G, Perfetti V, Obici L, et al. Association of melphalan and high-dose dexamethasone is effective and well tolerated in patients with AL (primary) amyloidosis who are ineligible for stem cell transplantation. Blood, 103(8): 2936-8, 2004.

[10] Kastritis E, Wechalekar AD, Dimopoulos MA, Merlini G, Hawkins PN, Perfetti V, Gillmore JD, Palladini G. Bortezomib with or without dexamethasone in primary systemic (light chain) amyloidosis. J Clin Oncol, 28(6): 1031-7, 2010.

[11] Moreau P, Jaccard A, Benboubker L, et al. Lenalidomide in combination with melphalan and dexamethasone in patients with newly diagnosed AL amyloidosis: a multicenter phase $1 / 2$ dose-escalation study. Blood, 116(23): 4777-82, 2010.

[12] Gertz MA, Comenzo $\mathrm{R}$, Falk $\mathrm{RH}$, et al. Definition of organ involvement and treatment response in immunoglobulin light chain amyloidosis (AL): a consensus opinion from the 10th International Symposium on Amyloid and Amyloidosis, Tours, France, 18-22 April 2004. Am J Hematol, 79(4): 319-28, 2005.

[13] Schönland SO, Dreger P, de Witte T, Hegenbart U. Current status of hematopoietic cell transplantation in the treatment of systemic amyloid light-chain amyloidosis. Bone Marrow Transplant. [Epub ahead of print July 25, 2011]. http://www.nature.com/bmt/journal/vaop/ ncurrent/full/bmt2011152a.html Accessed November 3, 2011

[14] Reece DE, Hegenbart U, Sanchorawala V, et al. Efficacy and safety of once-weekly and twice-weekly bortezomib in patients with relapsed systemic AL amyloidosis: results of a phase 1/2 study. Blood, 118(4): 865-73, 2011.

[15] Dispenzieri A, Lacy MQ, Zeldenrust SR, et al. The activity of lenalidomide with or without dexamethasone in patients with primary systemic amyloidosis. Blood, 109(2): 465-70, 2007. 